\title{
Survey for the intensity of anthracnose disease of banana caused by Colletotrichum musae in northern parts of Karnataka
}

\author{
RANI R. UNNITHAN* AND N. THAMMAIAH \\ College of Horticulture, Yalachahally Horticulture Farm, Yelwala, MYSORE (KARNATAKA) INDIA
}

\section{ARITCLE INFO}

Received : 25.07 .2017

Revised : 29.08 .2017

Accepted : 11.09 .2017

\section{KEY WORDS :}

Roving survey, Anthracnose disease, Colletotrichum musae

*Corresponding author:

\begin{abstract}
:
Banana anthracnose caused by Colletotrichum musae is one of the major post harvest disease. Present research was aimed at studying the intensity of banana anthracnose in major banana fruit markets of Belgaum and Bagalkot districts of Karnataka. Roving survey was conducted in major banana fruit markets of Belgaum and Bagalkot districts of Karnataka during 2013-2014 and it revealed that the intensity of the disease ranged from ten to thirty eight per cent. The highest intensity of 38.00 per cent was recorded in Belgaum and Munavalli on Grand Naine cultivar and the least intensity of the disease was recorded in Munavalli (13.00\%) on Rajapuri cultivar.
\end{abstract}

How to view point the article : Unnithan, Rani R. and Thammaiah, N. (2017). Survey for the intensity of anthracnose disease of banana caused by Colletotrichum musae in northern parts of Karnataka. Internat. J. Plant Protec., 10(2) : 378-380, DOI : 10.15740/HAS/IJPP/10.2/378-380. 